\title{
QURANIC FORENSIC ON BEGGING: FORMULATING POLICIES AND ACTION PLANS TO HANDLE STREET BEGGARS
}

\author{
YUSUF HANAFI*, M. ALIFUDIN IKHSAN, \\ TSANIA NUR DIYANA, ZUROIDAH ZENI NURUSHOFA \\ Universitas Negeri Malang
}

\section{Abstract}

Begging behavior is a serious issue and happens on a wide scale, especially in urban areas. In Islamic normative point of view, the Quran has a distinctive perspective towards beggars. In Sura alMā'ūn [107]: 3, Allah swt. encourages Moslem people to pay attention to poor beggars. In contrast, in other verses, al-Jāthiyah [45]: 7, al-Quran criticizes people who are lying for the sake of other's mercy with a mode and guise of a falsehood. In fact, the begging behavior nowadays is not only caused by the economic problem, but beggars even make it as a preferable profession. The biggest problem in handling the beggar issues is the difficulty to differentiate between the genuine and the professional beggar. If we examine thoroughly using an analysis of the Quran verses, there is a distinctive characteristic of those beggars. These at least can be identified through the micro-expression, sound pressure, and eye tracking. The analysis of the human's track and physical fact through al-Quran here is what the authors intend as Quran forensic. Based on the distinguishing indicators from the analysis of the Quran forensic, this article found a new model for solving beggar problems with a multidisciplinary approach.

Perilaku mengemis adalah masalah serius dan terjadi dalam skala luas, terutama di daerah perkotaan. Dalam sudut pandang norma Islam, al-Quran memiliki perspektif yang berbeda dengan para

\footnotetext{
* Corresponding author: Yusuf Hanafi, Jl. Semarang 5 Malang, Indonesia 65145. E-mail: yusuf.hanafi.fs@um.ac.id.
} 
pengemis. Dalam surah al-Mā'ūn [107]: 3, Allah swt. mendorong orang-orang Muslim untuk memperhatikan para pengemis miskin. Sebaliknya, dalam ayat-ayat lain, al-Jāthiyah [45]: 7, al-Quran mengkritik orang yang berbohong demi belas kasihan orang lain dengan cara dan kedok kepalsuan. Sebenarnya, perilaku mengemis saat ini tidak hanya disebabkan oleh masalab ekonomi, tetapi pengemis bahkan menjadikannya sebagai profesi yang lebih disukai. Masalah terbesar dalam menangani masalah pengemis adalah sulitnya membedakan antara pengemis asli dan profesional. Jika kita teliti dengan seksama menggunakan analisis ayat-ayat Al-Quran, ada ciri khas pengemis-pengemis itu. Setidaknya ini dapat diidentifikasi melalui ekspresi mikro, tekanan suara, dan pelacakan mata. Analisis jejak manusia dan fakta fisik melalui al-Quran di sini adalah apa yang penulis maksudkan sebagai forensik Quran. Berdasarkan indikator yang diperoleh dari analisis forensik al-Quran, artikel ini menemukan model baru penyelesaian masalah pengemis dengan pendekatan multidisiplin.

Keywords: beggar behavior; genuine beggar; professional beggar; Quran forensic.

\section{Introduction}

Beggars can almost always be found in the realities of life, especially in urban areas and other crowded locations. Nationally, the issue of begging behavior is considered very serious because it occurs on a wide scale in Indonesia. Ironically, the current begging behavior is not just driven by urgent economic conditions. Instead, it is made as an option of a profession. The raid conducted by the East Jakarta Social Service Supervision and Control Officer (P3S) at Taman Mini Indonesia Indah on Sunday, May 21, 2017, succeeded in seizing a person with social welfare problems who earns Rp. 100.000 or USD 7.5 in just one hour (Nailufar 2017). If the beggar is assumed in action for 10 hours/day, then the income earned is Rp. 1.000.000 or USD 75. Such nominal is much greater than the salary of a civil servant. 
The problems that formerly mentioned about begging behavior are not adequate to be seen only from the economic, social, and cultural aspects, but also needed to be viewed from the mental side and characters of the perpetrators. Generally, beggars are willing to mortgage their self-esteem in order to gain the mercy of others. They do not hesitate to perform in a variety of modes and theatrical acts, such as stump limbs, stinging disgusting ulcers, and suchlike. For example, a beggar with the mode of a stump arm was caught in a raid on the South Jakarta Social Service on July 18, 2016, which, after being examined by his hands, was perfectly fine and complete (Prasetya 2016). That is why the community is bipolar in response to the beggar. Some still care about them, but some are skeptical, antipathy and even furious with their existence.

From an Islamic point of view, the Quran has a distinctive perspective of the beggar's attitude. In Sura al-Mā'ūn [107]: 3, Allah swt. advises Muslims to care for the poor and beggars. On the contrary, in another verse, al-Jāthiyah [45]: 7, the Quran denounces those who lie in order to gain the compassion of others by the mode and the guise of a falsehood, even declaring it to be a sin.

In line with the Quran's criticism of the aforementioned misconduct, the Jakarta Council of Ulama (MUI) forbids the public to sponsor the beggars who operate in public spheres. The basic consideration is that beggars are begging not because of economic urgency, yet they choose it as a profession. The City Government of Malang also appealed to the community not to provide compensation, either in the form of money or goods, to street beggars, as stated in local regulation number 9 of 2013 on the handling of street children, homeless, and beggars.

If carefully examined, the genuine beggar and the professional beggar have distinctive characteristics. The differences 
between the two can be identified at least through micro-expression, eye tracking, and speech tone (Wu, Fu, and Yang 2012). Interestingly, the authors find a number of Quranic verses that talk about the forensics of human organs. This forensic study will be explored by the authors in this paper.

The research about begging problems have actually been done before. Namwata, Mgabo, and Dimoso (2012) studied street beggars in Central Tanzania and the factors that encouraged them to beg. In his research, Namwata and Mgabo (2014) identified street beggars into four categories: beggars on the streets, beggars of the streets, beggars in the streets, and beggars of street families. The driving factors of begging behavior are poverty, unemployment, physical disability, parental death, and divorce. Similar research was conducted by Onagun, et al. (2016) by taking a location in Nigeria that seeks a correlation between begging behavior and the poverty problem that plagues the perpetrators. The finding, there is a strong correlation between them both (Onagun 2016).

The research on begging behavior was also carried out in Indonesia. Kurniadi (2014) identified that the causative factors can be grouped into two, namely external factors (such as not having the capital to open a business, the difficulty of getting a job, the lure of high income from begging, offspring from parents who are beggars, environmental influences that the majority of whom become beggars) and internal factors (suffering from illness and laziness). Susanto and Yuhandra (2018) in their research found that beggars operate in groups and are organized. They tend to move around begging places to get more income. The modes they use are: laying hands, placing and carrying a bowl, and carrying a small child.

Different from previous studies, the authors want to explore the Quranic perspective on begging behavior, with the target of 
obtaining distinguishing indicators between the genuine beggar and the professional beggar based on the Quran forensic study. The study of the problems of begging with the Quran analysis to get the handling formula has not been done before.

Through this study, the author aims at formulating policy plans and action plans which will be proposed to the Government and the private sectors in handling beggar issues. One form is the development of educational digital media in the form of 3D and Augmented Reality Books for Beggar Issue (the 3D-Based Reality of Beggars Book) which is expected to help the community to address the variety of beggars.

This study is very strategic and urgent, for the following four reasons. First, it is in line with the objectives of the Nation contained in the constitution of the Republic of Indonesia (UUD NRI) year of 1945 which mandates to promote the general welfare. Second, it is in accordance with the global campaign to increase the Human Development Index (HDI), which in 2016 Indonesia still occupies rank 113 th of 188 countries of the world. Third, it is in line with one of Indonesia's Sustainable Development Goals (SDGs), i.e. without poverty in 2030. Fourth, it is in line with the ongoing mental revolution campaign echoed by the Government of the Republic of Indonesia lately.

This paper intends to: (1) describe the conception of beggars in the perspective of the Quran and the theory of Social Psychology; (2) to identify the variety of beggars based on the Quran forensic study; and (3) to design the prototype of policy models and action plans in handling macro beggar problems. The authors expect that by understanding the distinction between beggars into two kinds (genuine beggars and professional beggars) people can be wiser in dealing with the beggars. In addition, the policy plan and action plan recommended by this paper were expected to contribute to solving the beggar problems holistical- 
ly and comprehensively. If this beggar problem can be handled appropriately and well, then the campaign of mental revolution, as stated in Nawacita Jokowi-Jusuf Kalla government can be realized, in order to realize the people of Indonesia with superior character and noble.

This paper is a qualitative study. The data used in this research were obtained from literature materials and field data around the world in relation to beggars. The data collection was done through the literature review relevant to the topic being discussed, and field observation (Newman 1999). Sources of data include Holy Quran, literature books, documents, newspapers, magazines, journals, and websites containing the required information, and field observations of the beggar's world. The collected data were classified by the type for the preparation of further analysis.

The collected data were analyzed by using content analysis technique that is studying texts carefully with the principle of objectivity. In the process of data analysis, varied inductive and deductive logic was used, as in qualitative research in general.

\section{Beggar in the Perspective of the Quran and Social Psychology Theory}

'Prosperity' means the condition of being successful or thriving, especially economic well-being (Webster 2019) or living in a safe, vigorous, wealthy, and apart from all kinds of disturbance (KBBI 2019). Social welfare is defined as a social, material, and spiritual order of life, accompanied by a sense of security and safety (Siregar 2008). Segal and Brzuzy (1998) stated that social welfare includes health, economic prosperity, spiritual happiness, and the quality of life of the people. Economic conditions that have not reached a level of prosperity and equality in which typically lead to an increased number of homeless and beggars, especially in urban areas. 
Along with the demographic explosion that resulted in an imbalance between the Indonesian population and the availability of employment, unemployment emerges as a concerning social issue. This condition, in turn, forces some elements of society to choose to beg for the fulfillment of their basic needs. Concerning the socio-economic problem above, Islam instructs its followers to set aside some of their sustenance for the poor by the order of zakah, infaq, and șadaqah. In fact, Allah swt. criticizes those who are reluctant to sympathize with the weak (du'afā'), as his word in Sura al-Mā'ūn [107]: 1-3, "Have you seen the one who denies the Recompense? For that is the one who drives away the orphan and does not encourage the feeding of the poor" (al-Mā'ùn [107]: 1-3).

Musțafa al-Marāghī mentioned that Allah swt. started this Sura with the word 'arayta' (do you know?). The question (istif$h \bar{a} m$ ) contained in the verse above shows the exaggerated meaning of wonder as well as informing the attributes of those who belied the day of judgment, yaum al-qiyamah. Their characteristic is to be arrogant to the weak and apply miserly to the poor (Al-Marāghī 1946, 892). In Sura al-Mā'ūn [107]: 3, Allah swt. mentions the sustenance donated to the poor by the term ta' $\bar{a} m$ al-miskin (food belonging to the poor). It is as if Allah swt. affirms that the wealth that a person possesses in it must have the right of the poor, whether those who ask for it openly or who restrain themselves from begging. That is, there is a strong relationship between beggars and poverty, where almost all beggars are poor. Those who are forced to beg, because of these economic problems, the authors stated as the genuine beggar.

Regrettably, the religious command to sympathize the weak is exploited and abused by some who are not necessarily mercy-worthy. They make begging as a profession, not because of economic urgency, but rather because of laziness and their reluc- 
tance to work. These beggars are not only present in poor and developing countries, but also in developed countries. Mukti research finds that at this time not a few people actually do the act of begging as a field of income (Mukti 2014). They do not hesitate to lie in running the action, by making public camouflage, such as acting with a disgusting ulcer, stump legs, carrying a weak toddler, and so forth. They are what the author identifies as a professional beggar. This shows the existence of acts of public deception done intentionally and structured. This is what is criticized by religion through the word of God in Sura al-Jāthiyah [45]: 7, "Woe to every sinful liar" (al-Jāthiyah [45]: 7).

Hasbi Ash-Shiddieqy (2000) mentioned that the lie is a sin that can plunge the culprit into accident and destruction. Based on the verse, begging under the guise of falsehood, as practiced by professional beggars, is clearly prohibited by religion and expressly declared as sinful. The prohibition of begging as a profession is also confirmed in the hadith, "whoever begs for himself is not fakir then he seems to eat the coals of fire" (HR. Ahmad).

However, we should not arbitrarily judge the behavior of begging as a whole that is wrong and forbidden. Rasulullah SAW states that begging is an act of haram, but is excluded for three groups:

"O Qabishah, begging is not lawful, except for three people: (1) someone who bears the debt of others, he may beg to pay it off, (2) a person who is struck by a disaster who spends his wealth, he may beg to get the rest of life, and (3) a man suffering from misery so that there are three people of his people say: "The fulan is really overwritten by misery", then it is permissible for him to beg until he gets the rest of life. Asking, in addition to the three cases, $\mathrm{O}$ Qabishah, is haram, and the person who eats the result is consuming the ill-gotten treasure." (HR. Muslim).

The problem of professional beggars, who are the focus of this study, deemed from the point of view of Social Psychology, 
can be explained as the gap between the actual state and the display shown. In this case, the underlying lie is the motivation to change the situation drastically, effortlessly, accompanied by tricks that are trained and planned. This is what Walczyk termed as the decision activation theory and action theory (ADCAT) theory (Walczyk et al. 2014).

If the above theory is associated with the problem of professional beggars, then it is matched. Since in them, there is a motivation to lie by showing a non-factual view. That is what drives them to do falsehood modes in order to close the gap between the actual conditions and the display shown. In fact, they are not reluctant to train it in a planned manner.

\section{Identification of Professional Beggars Indicator Based on the Quran Forensic}

The biggest problem in handling beggar problems is the difficulty of distinguishing between the genuine beggar and the professional beggar. This identification is necessary as a prerequisite for handling the problem that is becoming increasingly serious, especially in urban areas and other crowded locations. In this section, the authors formulate the distinguishing indicator between the genuine beggar and the professional beggar through a forensic study of the Quran.

Forensic science is a branch of medical science that deals with the application of media facts to legal issues (KBBI 2019), it is the application of scientific principles and techniques to matters of criminal justice especially as relating to the collection, examination, and analysis of physical evidence (Merriam-Webster 2016). The forensics of the Quran is a study used to assist the process of enforcing justice through the implementation of the Quranic universal values. Traces of real forensic studies can be traced in the Quran, as implied in Sura Yāsin [36]: 65, "That Day, We will seal over their mouths, and their hands will speak to Us, and their feet will testify about what they used to earn". 
The verse describes the events that will occurr on the calculation day, yaum al-hisāb. At that time, human mouth will be locked so it cannot do self-defense because human tongue is "good" at lying. Instead, the testimony is a limb, such as hands, feet, skin, and others. This verse implicitly teaches us about the science of Quran forensic, where the information is not only obtained from verbal speech alone but also can be obtained from other sources, such as parts of the human body.

The Quran forensic study of beggars is emphasized on the three points of the body parts, namely: micro-expression, sound pressure, and eyes. These three aspects are the basis for the identification of the genuine beggar and professional beggar in order to distinguish between the two. Here are the descriptions of distinguishing indicators of beggar based on the Quran forensic in figure 1.

\section{Figure 1}

Indicators of distinguishing the genuine beggar and professional

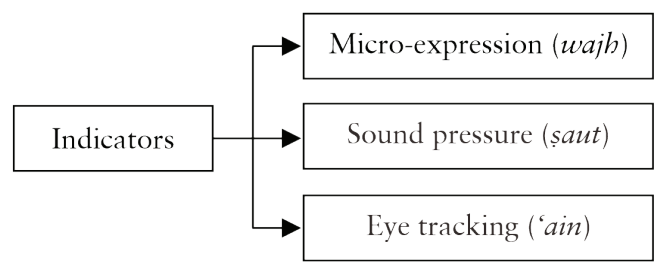

\section{Detection of Beggar through Micro-Expression}

Facial expression recognition is one of the hot spots in recent years, it applies in the emotional analysis, pattern recognition, and interpersonal interaction. There are many studies that link the change in facial expression when the person performs a positive or negative activity. Normally, it is obvious when he speaks honestly or lies. This reflex is temporary and lasts so fast that it is sometimes difficult to detect by the human eye. This phenomenon is commonly known as a micro-expression (Guo- 
jiang, Guoliang, and Kechang 2010; Kaulard et al. 2012). Utilization of micro-expression actually has been implied in Sura Muhammad [47]: 30, "And if We willed, We could show them to you, and you would know them by their mark".

According to Ibn Kathīr in his commentary, the intent of the above verse is that if Allah wills, He can reveal to the Muslims the hypocritical persons who live with them. However, Allah does not do that and invites Muslims to recognize themselves through the signs on their faces (simmāhum) (Ibn Kathīr 2001, 709)

If it is associated with a beggar case, the above verse has a strong relevance. From the results of the authors' in-depth observation of beggars who operate in public facilities in Malang East Java, beggars professions that do lies when acting it can be recognized from the expression on his face. Among the faces that imply the lie are: (1) the lack of awareness of what the say; (2) a facial aura that suggests falsehood; (3) expression without sincerity.

Based on the field findings above, it can be concluded that a micro-expression is a brief facial movement which reveals a genuine emotion that a person tries to conceal (Ekman and Friesen 1969; Yan et al. 2013). In addition, micro-expressions might be unaware and/or uncontrollable to the actor, thus may provide effective clues for detecting lies.

Detection of Beggar through Speech

Another indicator that can be used to recognize professional beggars is the tone of their speech, as indicated by Sura Muhammad [47]: 30, "You will surely know them by the tone of [their] speech. And Allah knows your deeds". The phrase 'the tone of speech' or 'labn al-qaul' in the above verse can be literally interpreted as 'speech tone'. In Ibn Kathīr's commentary, it is mentioned that through conversation, one can be known as the intensity by the interlocutor (Ibn Kathīr 2001, 709). 
Ekman's research emphasized that the speaking ability of the offender will decrease as they lie (Ekman and Friesen 1969). Professor of Psychology at Washington University, Mitchell S. Sommers in his research entitled "Research Casts Doubt on Voice-Stress Lie Detection Technology" explains that a sound analysis can be applied as a lie detection technique (Everding 2004). The identification of professional beggars through sound pressure can be done by detecting the following: (1) the answer is not spontaneous; (2) tortuous speech; and (3) the speech deemed as forcing.

Voice-stress analysis, as a method for lie detection, is already widely used in fraud investigations. Despite its booming popularity, a number of studies have found little or no scientific evidence to support the notion that existing voice-stress technologies are capable of consistently detecting lies and deceptions. Therefore, this study of sound pressure based on Quran forensics can be an alternative development approach in the future.

\section{Detection of Beggars through Eye Tracking}

The next indicator that can be used to identify a professional beggar is the eye tracking, as taught by Sura Ghāfir [40]: 19, "He knows that which deceives the eyes and what the breasts conceal". In this verse, there is a word of khä'inat al-a'yun which means 'a treacherous look'. The verse teaches that one way of detecting lies is through eye tracking.

From the point of view of modern technology, it is known Eye Tracking Lie Detection application which is developed by Webb from Utah University (Webb et al. 2009). The way it works is by measuring one's cognitive reactions based on pupil dilation and the duration of response time. If this technique is applied as a formula for the identification of a beggar, then the eye tracking indicating lies can be measured by the following variables: (1) unfocused eyesight; (2) upward-looking eyes; (3) the dilated pupils. 
The accuracy of eyewitness testimony has expanded dramatically in recent years. This study introduces cognitive load on liars. The cognitive cues were response time, answer consistency, eye movements, and pupil dilation. Moreover, they generally had more eye movements, suggesting low cognitive loads.

\section{Formulating Policy and Action Plan to Handle Begging Behavior Problems}

At the national level, there are a number of legal products that prohibit the act of begging and giving alms to beggars. Among them are the Book of the Penal Code Article 504 on the criminal act of public order violation, and the Government Regulation of the Republic of Indonesia Number 31 Year 1980 on Counterfeit and Beggar which states that the begging is not in accordance with Indonesian life norms based on Pancasila and the 1945 Constitution of the Republic of Indonesia.

At the local level, there are several legal products for the handling of beggars, such as Regional Regulation of DKI Jakarta Province No. 8/2007 Article 40 on Public Order, and Malang City Number 9 the Year of 2013 Article 16 Paragraph 1 on Handling of Street Children, and beggars. In addition to the above two local regulations, there are still many similar regional regulations in other regions. The Indonesian Ulema Council (MUI) as a religious institution also issues a fatwa on the beggar's issue, even though the fatwa is simply at the level of moral control. The strong reason behind the MUI issued the fatwa was because the beggar was coordinated in certain networks even leading to human trafficking (Detik 2013).

Although many legal products have been published in the form of regional regulations or others, in reality, it has not been able to solve the problem of begging behavior (Prasasi, Tyesta, and Herawati 2016). The rule is only a ban without the presence of curative action. In this context, this work is present to formu- 
late a policy plan and action plan which will be recommended for the government and private for the handling of the beggars in the country.

Furthermore, in handling the professional beggars it needs to be done comprehensively. Efforts to handle beggars can be done on a large scale, both by the government and non-government organization (NGO). If necessary, the anti-begging movement of the profession is massively campaigned and worked comprehensively in all sectors of life, as illustrated in figure 2.

Figure 2

The policy of handling beggars synergistically through circular formula

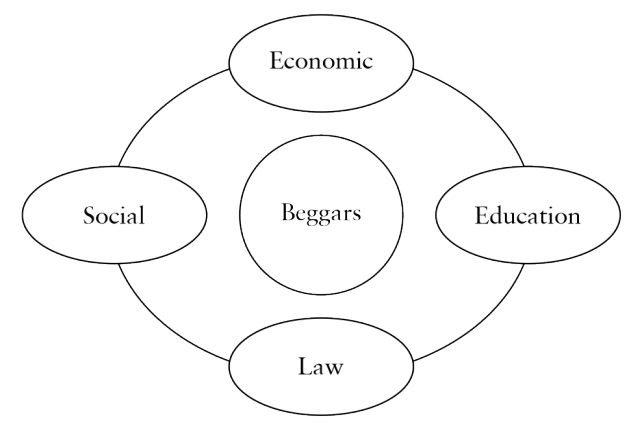

The circular formula is necessary since the handling of this beggar problem must be done synergistically. Here is the exposure of the policy plan and action plan to minimize the practice of professional beggars.

National Strategic Policy for Handling beggar

Strategic policies for handling beggar issues need to be made in various sectors, covering the social, economic, legal, and educational fields as can be seen in table 1 . In the social field, cooperation with various agencies, such as the Ministry of Social Affairs and the Central Bureau of Statistics (BPS), is required for data collection and rehabilitation. In the economic field, the handling of beggars can be realized through community eco- 
nomic empowerment programs, such as Small and Medium Enterprises (SMEs) and others. In the legal field, the government needs to make a political commitment (and clear statement to handle professional beggars.

\author{
Table 1 \\ National strategic policy for handling beggar problems
}

\begin{tabular}{|c|c|}
\hline Fields & Policy Plans \\
\hline Social & $\begin{array}{l}\text { There needs to be cooperation with social welfare institutions and } \\
\text { Central Bureau of Statistics (BPS), the first step that can be done is } \\
\text { to cooperate with BPS in the data collection of beggars on a regular } \\
\text { basis. After that, beggars who got seized can get rehabilitation } \\
\text { and given motivation, which can be done by cooperating with the } \\
\text { Ministry of Social Affairs. }\end{array}$ \\
\hline Economic & $\begin{array}{l}\text { Encouraging the acceleration of economic and welfare } \\
\text { improvements through the provision of feasible and adequate } \\
\text { employment. Since weak-economy families usually take the } \\
\text { action of begging as a profession that is easy and promising; } \\
\text { - Equitable development in order to avoid welfare gaps between } \\
\text { community groups and structural poverty. } \\
\text { - Cooperating with ministries of Cooperatives and SMEs (Small } \\
\text { and medium-sized enterprises) in the formation of cooperatives } \\
\text { that overshadow former beggars. }\end{array}$ \\
\hline Law & $\begin{array}{l}\text { The government is required to make the political commitments } \\
\text { and clear statements for the handling of beggars who try to return } \\
\text { to the streets. One form is to ratify and effectively apply the legal } \\
\text { instruments especially those related to the handling of beggars. }\end{array}$ \\
\hline
\end{tabular}

\title{
Strategic Programs to Handle the Beggars
}

The strategy of handling the beggar problem is contained in the blueprint of the action plan as can be seen in table 2 .

Table 2

Strategic programs to handle the beggars

\begin{tabular}{ll}
\hline \multicolumn{1}{c}{ Action plans } & \multicolumn{1}{c}{ Programs and Strategies } \\
\hline $\begin{array}{l}\text { Dissemination of distinguishing } \\
\text { indicators of beggars based on } \\
\text { the Quran forensic study to the } \\
\text { community }\end{array}$ & $\begin{array}{l}\text { Audio-Visual programs (PAV), such as videos, } \\
\text { pamphlets, stickers, and educational packages } \\
\text { about begging practices and identification of } \\
\text { beggar mode through the study of the Quran } \\
\text { Forensic }\end{array}$ \\
\hline $\begin{array}{l}\text { Education to children through } \\
\text { augmented reality-based media }\end{array}$ & $\begin{array}{l}\text { The development of educational media in } \\
\text { the form of 3D-Augmented Reality Book } \\
\text { for Beggar Issue (Three-Dimensional Beggar } \\
\text { Reality Book). }\end{array}$ \\
\hline
\end{tabular}


The aforementioned blueprints are (1) dissemination of the beggar's distinguishing indicators to the community based on the Quran forensic study through educational videos; (2) the development of educational media in the form of 3D augmented reality book for beggar issue.

To provide an overview of product development procedures, the following flowchart is provided as can be seen in figure 3.

Figure 3

The work process of $3 D$ media augmented

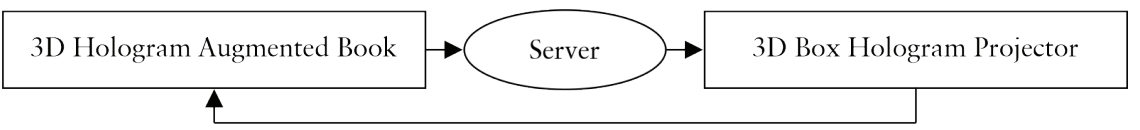

The design of this educative media system includes the design of hardware and software. The design of hardware includes a monitor, reflective glass, laptop, and connecting cable. The design of the software includes designing Augmented Reality program using 3D hologram app via a wireless network.

To find out the steps of use of 3D augmented reality book for beggar issue, the following figure 4 describes the flowchart of its use.

Figure 4

Flowchart of the use of angmented reality media

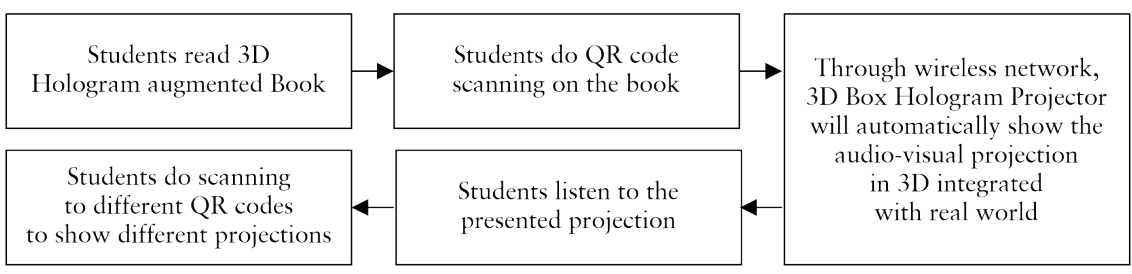

The above 3D augmented reality media is very suitable for educating children and adolescents in the wisdom of beggars. This medium can be used in two sections. First, introducing the suggestion of charity. In this section, learners are given an 
overview of the suggestions to help the weak as taught in Sura al-Mā'ūn [107]: 1-3. Suggestions of charity are shown in 3D with sound accompaniment. Second, describing the variety of beggars. In this section, the various beggars are displayed. From some examples of available photos of beggars, the identification is done through the characteristics obtained through the Quran forensic study. It is expected that the learners are able to recognize the professional beggars and respond it wisely.

The policy plan and action plan (PP \& AP) above are a package of policy plans and action plans designed with links to several aspects that are synergistically complementary. The author realizes that the problem of beggars is not a problem that can be handled only through one aspect only, but necessary linkage with other sectors. In the execution of PP \& AP, one of the things highlighted is on the aspect of education through $3 \mathrm{D}$ educational media and Augmented Reality Book for Beggar Issue to provide insight to the general public regarding the variety of beggars.

In addition, the implementation of this idea is carried out with the following stages: (1) the government enforces the law fairly with regard to the beggar's problems, building awareness of the community so as not to nurture the existence of professional beggars; (2) Programmers in the field of Technology, translating the concept designed by researchers in the form of applications and continuing to develop in the field of technology so that later applications can be produced maximally; (3) The community is more selective when giving the charity.

The PP \& AP can be applied in a wide sphere so that the welfare of society will be achieved. In the implementation of PP \& AP brings the concept of 3D Augmented Reality for beggar issue will provide great benefits for the world of education, especially in preventive steps to respond to beggars. Predicted 
results will be obtained by using this concept is the reduction in the number of beggars because the community will be more selective and wise in dealing with beggars.

\section{Conclusions}

The biggest problem in handling beggar problems is the difficulty of distinguishing between the genuine beggar and the professional beggar. If carefully examined, between them there are characteristics that are distinctive. It can at least be identified through micro-expression, speech, and eye tracking, through the study of verses of the Quran. The study of the traces and physical facts of man through these verses of the Quran is what the author means by the Quran forensic.

The detection of professional beggars through facial expressions is implied in Sura Muhammad [47]: 30. Among the micro-expressions that imply the lie are: (1) the lack of awareness of what the say; (2) a facial aura that suggests falsehood; (3) expression without sincerity. Subsequent detection is through speech tone as implied in Sura Muhammad [47]: 30, where a professional beggar can be identified through the following things: (1) the answer is not spontaneous; (2) tortuous speech; and (3) the speech deemed as forcing. The detection through the eyes is taught in Sura Ghafir [40]: 19. The eye tracking indicating lies can be measured by the following variables: (1) unfocused eyesight; (2) upward-looking eyes; (3) the dilated pupils.

Based on the distinguishing indicators between the genuine beggar and the professional beggar obtained from this Quran forensic study, the authors formulate the policy plan and action plan recommended for the government and the private sectors. The goal is that the handling of beggars can be done synergistically by involving many parties. The working area also focuses not only on one particular area but covers the educational, economic, social, and law worked circularly. The real contributions 
that the authors embody through this work are (1) dissemination of the beggar's distinguishing indicators to the community based on forensic study of the Quran through educational videos; (2) the development of educational digital media in the form of 3D and Augmented Reality Books for Beggar Issue (The Three Dimensional-Based Beggar Reality Book). The presence of the solutions is expected to make people aware to be wiser in responding to the beggars.

\section{Acknowledgments}

We are grateful to thank to the members of al-Quran Study Club (ASC), researches, developers and students. This research is supported by State University of Malang (UM) and held on funding of research grant 4 in 1 Islamic Development Bank (IsDB) year 2018 .

\section{Bibliography}

Al-Marāghī, Ahmmad Musțafa. 1946. Tafsīr Al-Marāghī. Cairo: Musțafa al-Bāb al-Halabi.

Ash-Shiddieqy, M. Hasbi. 2000. Tafsir Al-Qur'anul Majid an-Nuur. Semarang: Pustaka Rizki Putra.

Detik. 2013. "MUI Sudah Haramkan Memberi Ke Pengemis Di Jalan.” Detik.Com. 2013. https://news.detik.com/berita/d2314452/-mui-sudah-haramkan-memberi-ke-pengemisdi-jalan.

Ekman, Paul, and Wallace V. Friesen. 1969. "Nonverbal Leakage and Clues to Deception." Psychiatry Interpersonal and Biological Processes 32 (1): 88-106. https://doi.org/10.1080 /00332747.1969.11023575.

Everding, Gerry. 2004. "Research Casts Doubt on Voice-Stress Lie Detection Technology." The Source - Washington University in St. Louis. 2004. https://source.wustl.edu/2004/02/ research-casts-doubt-on-voicestress-lie-detection-technology/. 
Guojiang, Wang, Yang Guoliang, and Fu Kechang. 2010. “Facial Expression Recognition Based on Extended Optical Flow Constraint." In 2010 International Conference on Intelligent Computation Technology and Automation, 297-300. IEEE. https://doi.org/10.1109/ICICTA.2010.777.

Kaulard, Kathrin, Douglas W. Cunningham, Heinrich H. Bülthoff, and Christian Wallraven. 2012. "The MPI Facial Expression Database - A Validated Database of Emotional and Conversational Facial Expressions." Edited by Marc O. Ernst. PLoS ONE 7 (3): e32321. https://doi. org/10.1371/journal.pone.0032321.

KBBI. 2019. "Kamus Besar Bahasa Indonesia.” Badan Pengembangan Dan Pembinaan Bahasa. 2019. https://kbbi.kemdikbud.go.id.

Kurniadi, Marselly. 2014. "Are We Still Giving Our Money to Beggars? Prosocial Intention in between of Religion, Emotion, Corruption, and Government Policy Advocacy.” Mediterranean Journal of Social Sciences, November. https:// doi.org/10.5901/mjss.2014.v5n23p1817.

Merriam-Webster. 2016. The Merriam-Webster Dictionary. Massachusetts: Merriam-Webster, Inc.

Mukti, Pramudita Ruh. 2014. "Strategi Pengemis Dalam Hidup Bermasyarakat Di Kota Surabaya.” Journal Universitas Airlangga 3 (1): 1-15.

Nailufar, Nibras Nada. 2017. "Pengemis Berpenghasilan Rp 100.000 Dalam 1 Jam Terjaring Di TMII - Kompas.Com.” Indonesia.

Namwata, Baltazar M.L., and Maseke R. Mgabo. 2014. “Consequences of Begging and Future Aspirations of Beggars to Stop Begging Life in Central Tanzania." International Research Journal of Human Resources and Social Sciences 1 (4): 176-87.

Namwata, Baltazar M.L., Maseke R Mgabo, and Provident Dimoso. 2012. "Categories of Street Beggars and Factors 
Influencing Street Begging in Central Tanzania." African Study Monographs 33 (2): 133-43. https://doi.org/https:// doi.org/10.14989/158998.

Newman, Lucile F. 1999. "Introduction to Qualitative Research Methods: A Guidebook and Resource." The Journal of Nervous \& Mental Disease 187 (9). https://doi. org/10.1097/00005053-199909000-00011.

Onagun, Abdussalam Isiaka. 2016. "Relationship Between Street-Begging and Poverty in Ilorin Emirate, Kwara State, Nigeria." International Journal of Health Economics and Policy 1 (1). https://doi.org/10.11648/J.HEP.20160101.12.

Prasasi, Cindy Ayu, Lita Tyesta, and Ratna Herawati. 2016. "Pelaksanaan Peraturan Daerah Kota Semarang Nomor 5 Tahun 2014 Tentang Anak Jalanan, Gelandangan Dan Pengemis." Diponegoro Law Journal 5 (2): 1-15.

Prasetya, Eko. 2016. "Mengemis Modus Tangan Buntung Di Pasfes, Pria Ini Raup Rp 200 Ribu.” Merdeka.Com. 2016. https://www.merdeka.com/jakarta/mengemis-modus-tangan-buntung-di-pasfes-pria-ini-raup-rp-200-ribu.html.

Segal, Elizabeth A., and Stephanie. Brzuzy. 1998. Social Welfare Policy, Programs, and Practice. Adelaide: F.E. Peacock Publishers.

Siregar, Chairil N. 2008. "Analisis Potensi Daerah Pulau-Pulau Terpencil Dalam Rangka Meningkatkan Ketahanan, Keamanan Nasional, Dan Keutuhan Wilayah NKRI Di Nunukan Kalimantan Timur.” Jurnal Sosioteknologi 7 (13): 345-68.

Susanto, Igit Wijaya, and Erga Yuhandra. 2018. “The Authority of The Civil Service Police Unit in Handling Beggars, Vagabonds And Derelicts in Kuningan District, Indonesia." Unifikasi: Jurnal Ilmu Hukum 5 (2). https://doi.org/10.25134/ unifikasi.v5i2.916.

Walczyk, Jeffrey J., Laura L. Harris, Terri K. Duck, and Devyani Mulay. 2014. "A Social-Cognitive Framework 
for Understanding Serious Lies: Activation-Decision-Construction-Action Theory." New Ideas in Psychology 34 (August): 22-36. https://doi.org/10.1016/J.NEWIDEAPSYCH.2014.03.001.

Webb, Andrea K., Charles R. Honts, John C. Kircher, Paul Bernhardt, and Anne E. Cook. 2009. "Effectiveness of Pupil Diameter in a Probable-Lie Comparison Question Test for Deception.” Legal and Criminological Psychology 14 (2): 279-92. https://doi.org/10.1348/135532508X398602.

Webster, Merriam. 2019. "Definition of Prosperity by Merriam-Webster.” Merriam-Webster Dictionary. 2019. https:// www.merriam-webster.com/dictionary/prosperity.

Wu, Ting, Siyao Fu, and Guosheng Yang. 2012. "Survey of the Facial Expression Recognition Research.” In Advances in Brain Inspired Cognitive Systems, edited by Wang Z. Zhang H., Hussain A., Liu D., 392-402. Springer, Berlin, Heidelberg. https://doi.org/10.1007/978-3-642-315619_44.

Yan, Wen-Jing, Qi Wu, Jing Liang, Yu-Hsin Chen, and Xiaolan Fu. 2013. "How Fast Are the Leaked Facial Expressions: The Duration of Micro-Expressions." Journal of Nonverbal Behavior 37 (4): 217-30. https://doi.org/10.1007/ s10919-013-0159-8. 